\title{
Climate change impacts on Yangtze River discharge at the Three Gorges Dam
}

\author{
Steve J. Birkinshaw ${ }^{1}$, Selma B. Guerreiro ${ }^{1}$, Alex Nicholson ${ }^{2}$, Qiuhua Liang ${ }^{1}$, Paul Quinn ${ }^{1}$, Lili Zhang ${ }^{3}$, Bin He ${ }^{4}$, \\ Junxian Yin ${ }^{3}$, and Hayley J. Fowler ${ }^{1}$ \\ ${ }^{1}$ School of Civil Engineering and Geosciences, Newcastle University, Newcastle, UK \\ ${ }^{2}$ Ove Arup and Partners, Admiral House, 78 East St., Leeds, UK \\ ${ }^{3}$ State Key Laboratory of Simulation and Regulation of Water Cycle in River Bain, China Institute of \\ Water Resources and Hydropower Research, Beijing, China \\ ${ }^{4}$ School of Hydraulic Engineering, Dalian University of Technology, Dalian, China \\ Correspondence to: Steve J. Birkinshaw (s.j.birkinshaw@ncl.ac.uk)
}

Received: 13 May 2016 - Discussion started: 23 May 2016

Revised: 17 February 2017 - Accepted: 8 March 2017 - Published: 5 April 2017

\begin{abstract}
The Yangtze River basin is home to more than 400 million people and contributes to nearly half of China's food production. Therefore, planning for climate change impacts on water resource discharges is essential. We used a physically based distributed hydrological model, Shetran, to simulate discharge in the Yangtze River just below the Three Gorges Dam at Yichang $\left(1007200 \mathrm{~km}^{2}\right)$, obtaining an excellent match between simulated and measured daily discharge, with Nash-Sutcliffe efficiencies of 0.95 for the calibration period (1996-2000) and 0.92 for the validation period (2001-2005). We then used a simple monthly delta change approach for 78 climate model projections (35 different general circulation models - GCMs) from the Coupled Model Intercomparison Project Phase 5 (CMIP5) to examine the effect of climate change on river discharge for 2041-2070 for Representative Concentration Pathway 8.5. Projected changes to the basin's annual precipitation varied between -3.6 and $+14.8 \%$ but increases in temperature and consequently evapotranspiration (calculated using the Thornthwaite equation) were projected by all CMIP5 models, resulting in projected changes in the basin's annual discharge from -29.8 to $+16.0 \%$. These large differences were mainly due to the predicted expansion of the summer monsoon north and west into the Yangtze Basin in some CMIP5 models, e.g. CanESM2, but not in others, e.g. CSIRO-Mk3-6-0. This was despite both models being able to simulate current climate well. Until projections of the strength and location of the monsoon under a future climate improve, large uncertainties
\end{abstract}

in the direction and magnitude of future change in discharge for the Yangtze will remain.

\section{Introduction}

The Yangtze (or Chang Jiang) River (Fig. 1) is the third longest river in the world $(6418 \mathrm{~km})$ and the longest river in Eurasia. Its source is located on the Qinghai-Tibet Plateau (also known as the Tibetan Plateau), at $5100 \mathrm{~m}$ elevation, and extends to the East China Sea through the city of Shanghai. The river basin covers an area of $1808500 \mathrm{~km}^{2}$ and is home to a population greater than 400 million (Dai et al., 2012). Industry and agriculture within the Yangtze River basin generates 30-40\% of China's GDP and the Yangtze River basin contributes nearly half of China's crop production, including more than two-thirds of the total volume of rice (Yang et al., 2005). The Yangtze River has been responsible for some of China's worst natural disasters. Catastrophic floods occurring over the last century include events in 1911, 1931, 1935 and 1954, which claimed the lives of over 300000 people. As recently as 1998, flooding of the Yangtze River caused over 4000 deaths, inundated $250000 \mathrm{~km}^{2}$ of agricultural land and cost in excess of USD 36 billion in damage to property and infrastructure (Yin and Li, 2001).

The Three Gorges Dam (TGD), which is located near Yichang, is the largest of more than 50000 dams which have been built in the Yangtze Basin (Li et al. 2013). The TGD 


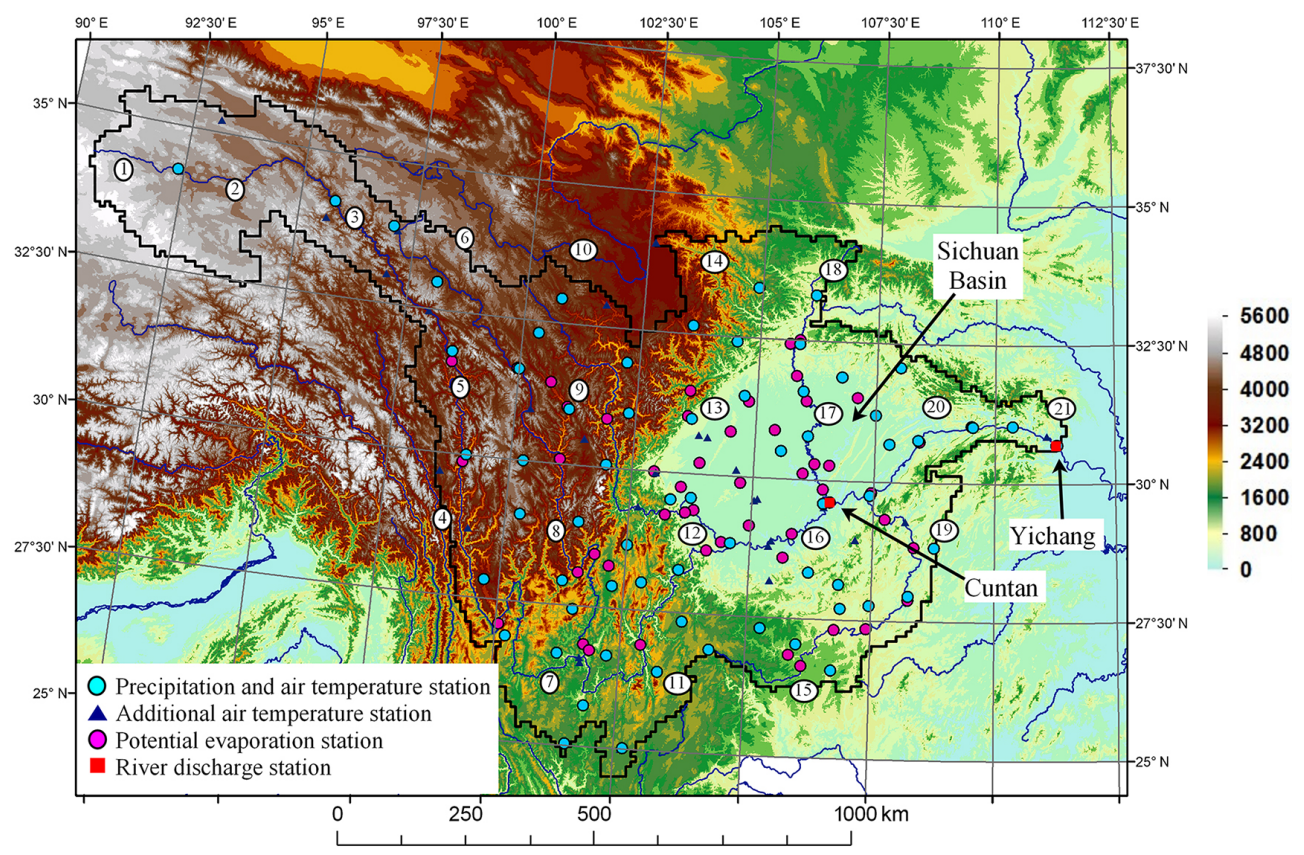

Figure 1. Yangtze River basin to Yichang $\left(1007200 \mathrm{~km}^{2}\right)$. CMIP5 outputs are available for each of the $2.5^{\circ}$ by $2.5^{\circ}$ grids numbered in the figure. In total, 21 CMIP5 grids within or close to the Yangtze Basin were used in this study. A total of 64 precipitation and air temperature stations are shown; also shown are the locations of an additional 26 air temperature stations where there are no precipitation data ( 90 in total). The locations of the 52 potential evaporation stations are shown.

reservoir is $600 \mathrm{~km}$ long with a surface area of $1084 \mathrm{~km}^{2}$ and storage of $39.3 \mathrm{~km}^{3}$ of water (Dai et al., 2006). It was built to help alleviate flooding on the Yangtze plain, for hydroelectric power generation and to improve upstream navigation. Construction finished in 2012, when it was the largest hydropower dam in the world in terms of installed capacity, with a maximum output of $23200 \mathrm{MW}$ from 34 turbines (Dai et al., 2006).

Over recent decades, the Yangtze has been at a boundary between decreasing precipitation in the north-east of China and increasing precipitation in the south-east $(\mathrm{Q}$. Zhang et al., 2011; Z. Zhang et al., 2011) due to the weakening of the East Asian summer monsoon (Wang et al., 2012). This has caused a small, but statistically insignificant, increase in discharge for the Yangtze Basin since 1960 but a persistent decrease further north in the Yellow River basin (Piao et al., 2010). Therefore, it is instructive to examine how climate change may impact river discharges in the Yangtze Basin, as any modifications to the seasonal distribution of precipitation and temperature may also have a major effect on flooding, water resources and hydropower generation in the TGD.

Using the most recent CMIP5 climate change projections (Taylor et al., 2012), there have been a number of studies considering future precipitation in the Yangtze. Tian et al. (2015) showed that for 22 CMIP5 models under RCP8.5 there was an overall increase in precipitation in China, but these increases were larger further north and only small increases were projected for the Yangtze. Sim- ilar results are also shown in Piao et al. (2010), Tao et al. (2012) and Jiang and Tian (2013). However, there have been no previous studies using the most recent CMIP5 climate change projections together with a hydrological model. Ma et al. (2010) considered terrestrial water storage changes within the Yangtze Basin using the variable infiltration capacity (VIC) macroscale hydrological model under the SRES A2 and B2 (Nakićenović et al., 2000) climate scenarios. These scenarios showed that the south-east and central parts of the basin had the highest annual variations in storage. Koirala et al. (2014) considered runoff from 11 CMIP5 models together with a routing model. They found little change in discharge from the Yangtze Basin but higher discharges further north in China due to the increased projected precipitation.

In this paper, the Shetran physically based distributed hydrological model is used to simulate river discharge for the Yangtze Basin (Fig. 1) to the TGD near Yichang $\left(1007200 \mathrm{~km}^{2}\right)$ for 10 years from 1 January 1996 to 31 December 2005. Other hydrological models have previously been applied to the Yangtze Basin (Hayashi et al., 2008; Woo et al., 2009; Xu et al., 2008), but in terms of grid resolution, this is the most detailed hydrological model that has been produced for a major part of this basin. Shetran is then run under a changed climate using a simple monthly delta change approach on the outputs of 35 atmosphereocean general circulation models (GCMs) (78 individual projections) from CMIP5 under Representative Concentration 

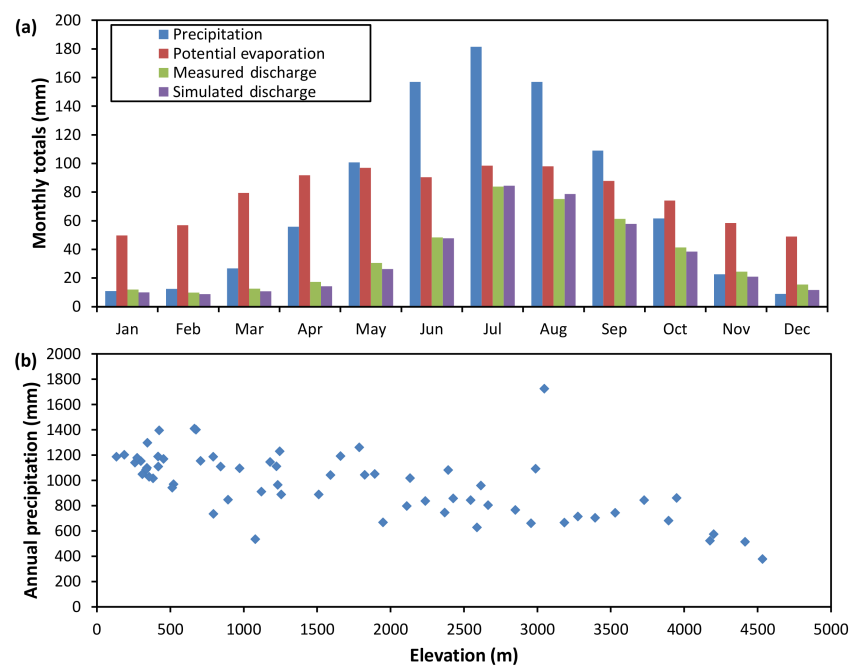

Figure 2. (a) Monthly precipitation, potential evaporation, measured and simulated discharge totals in the Yangtze Basin to Yichang (1996-2005). (b) Comparison of the elevation of the precipitation station and the annual precipitation totals.

Pathway (RCP) 8.5. The results from the CanESM2 and CSIRO-Mk3-6-0 models are then considered in detail.

\section{Data and methods}

\subsection{Time series data}

Most of the Yangtze (apart from the Tibetan Plateau) has a subtropical monsoon climate. This has a distinct wet season (May-September) with high precipitation totals and high temperatures. We use observed daily data for 1 January 1996-31 December 2005 for 64 precipitation stations, 90 air temperature stations and 52 potential evapotranspiration (PET) stations (see Fig. 1 for station locations) - evaporation pans, with Thiessen polygons used to assign the spatial distribution in each case. Figure 2a shows the annual cycle of precipitation, PET, measured and simulated discharge totals in the Yangtze Basin to Yichang from 1996 to 2005. The highest precipitation and PET totals are in July; discharge totals are highest from July to September.

Figure 3a shows the Thiessen polygon annual precipitation totals over the Yangtze Basin. Annual totals vary from $370 \mathrm{~mm}$ on the Tibetan Plateau, up to $1400 \mathrm{~mm}$ near the TGD. Thus, there is a general trend of decreasing annual precipitation with increasing elevation but there is also considerable variation depending on the location of the precipitation station within the basin (Fig. 2b). The highest annual precipitation, $1700 \mathrm{~mm}$, is observed at gauge 56385 at the western edge of the Sichuan Basin; at only $100 \mathrm{~km}$ from the highest point in the basin at Mount Gongga $(7556 \mathrm{~m})$, there may be some orographic effects at this location. Figure $3 \mathrm{~b}$ shows Thiessen polygon mean annual air tempera-

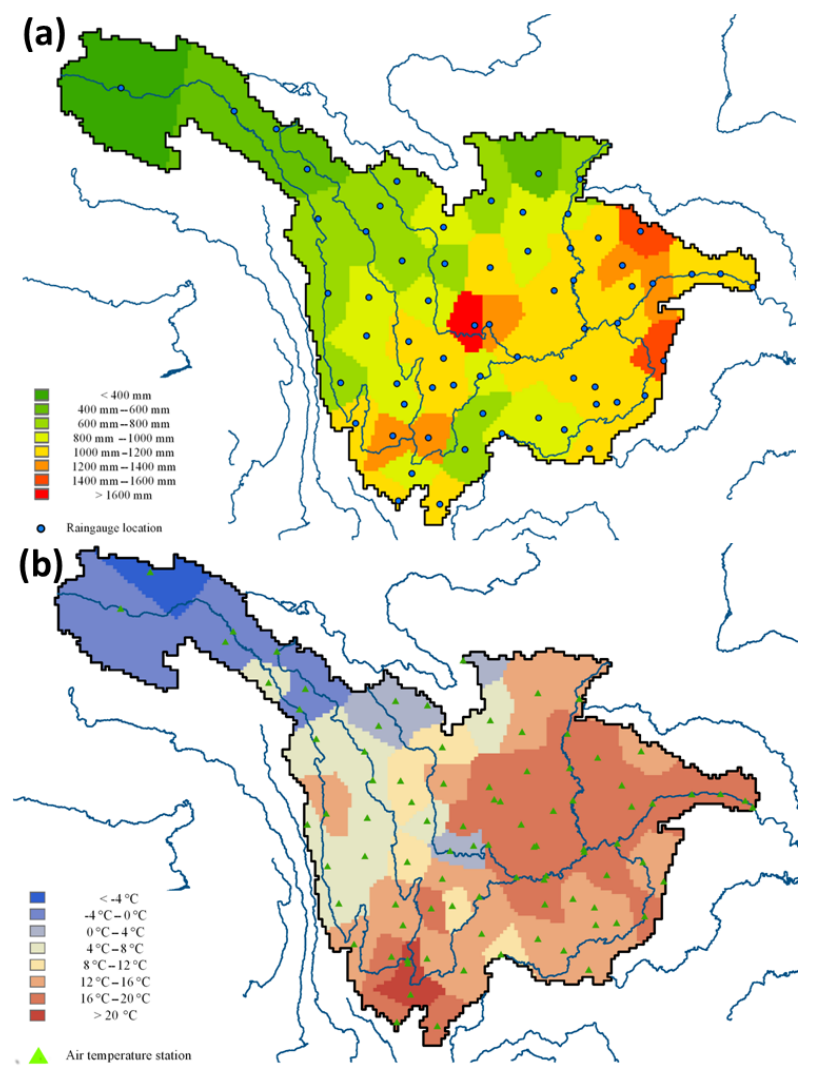

Figure 3. (a) Annual precipitation totals at stations within the Yangtze Basin; Thiessen polygons are used to assign the spatial distribution to Shetran. The high value (gauge 56385) at the western edge of the Sichuan Basin is discussed in the text. (b) Mean annual air temperatures over the Yangtze Basin; Thiessen polygons are used to assign the spatial distribution to Shetran.

ture over the Yangtze Basin. Temperature shows considerable spatial variation across the basin with mean average annual air temperature ranging from $-4.5^{\circ} \mathrm{C}$ on the Tibetan Plateau to $21.3^{\circ} \mathrm{C}$ towards the southern edge of the basin. Average monthly temperature over the basin ranges from $-5^{\circ} \mathrm{C}$ in January to $16^{\circ} \mathrm{C}$ in July. Daily potential PET also shows considerable spatial variation, ranging from an annual total of $600 \mathrm{~mm}$ on the Tibetan Plateau to $1300 \mathrm{~mm}$ near the TGD.

We also used daily discharge data from Yichang for 1 January 1996 to 31 December 2005 (see Fig. 1 for location). Yichang is downstream of the TGD, and in May 2003 the dam began to retain water. More details of the effect of the dam on discharges at Yichang are discussed in Sect. 3.1.

\subsection{Shetran}

Shetran (http://research.ncl.ac.uk/shetran/) is a physically based distributed modelling system for water flow, sediment and solute transport in river basins (Ewen et al., 2000; Birkinshaw et al., 2010). The most convenient way of visualizing Shetran is as a set of vertical columns with each column di- 
vided into finite-difference cells. There are 10072 vertical columns, each of which is $10 \mathrm{~km}$ by $10 \mathrm{~km}$, with each column divided into up to 25 finite-difference cells (making a total of around 250000 finite difference cells). The lower cells contain aquifer materials and groundwater, higher cells contain soil and soil water and the uppermost cells contain surface waters and the vegetation canopy. River channels are specified around the edge of the finite-difference columns and the location and elevations of these channels were calculated automatically using the method demonstrated in Birkinshaw (2010). Overall, 4143 river channel sections were specified.

Digital elevation model data were extracted from the Shuttle Radar Topography Mission (SRTM) $90 \mathrm{~m}$ grid resolution dataset (http://srtm.csi.cgiar.org/). Land use for each grid square was obtained from the $1 \mathrm{~km}$ resolution Global Land Cover map for the year 2000 (Bartholome et al., 2002), with the data acquired from an instrument onboard the SPOT 4 satellite. The Asian dataset has 31 classes, although some of these were not present over the Yangtze Basin and some were present in very small numbers. Overall, there were seven main categories used in the Shetran simulations (Table 1). In the high-elevation Tibetan Plateau, the main vegetation is shrub and/or herbaceous and deciduous forest. The rest of the basin is mostly cropland and rice paddies with evergreen forest around the steep edge of the Sichuan Basin. There has been little change in forest cover within the Yangtze Basin in recent decades (Hansen et al., 2013). The most significant change has been the urbanization within the Sichuan Basin but this increase covers less than $1 \%$ of the Sichuan Basin (Liu et al., 2010).

Most of the parameters were based on values from the literature (Breuer et al., 2003). However, transpiration depends on the actual/potential evapotranspiration (or crop coefficient) and this value was calibrated by taking into account differences between land-use types from previous simulations (e.g. Bathurst et al., 2011; Birkinshaw et al., 2014).

The soil profile for each Shetran grid square comes from the $1 \mathrm{~km}$ grid resolution HWSD database (www.fao.org/nr/ water/news/soil-db.html; FAO/IIASA/ISRIC/ISSCAS/JRC, 2012). The Chinese data in this database come from the Institute of Soil Science, Chinese Academy of Sciences, which provided the recent $1: 1000000$ scale soil map of China. For each grid square, the dataset gives the texture type of the topsoil $(0-30 \mathrm{~cm})$ and, where it exists, the subsoil $(30-100 \mathrm{~cm})$. These data were aggregated up to the $10 \mathrm{~km}$ Shetran grid squares, with the soil profile chosen being the most dominant in that square. Overall, this gave 930 soil profiles. Generally, the higher-elevation region has shallower soils and a sandy loam texture as opposed to a loam or clay loam texture in the lower elevation regions. Using the Hypres v2.0 database (http://esdac.jrc.ec.europa.eu/ESDB_Archive/ ESDBv2/fr_intro.htm; Wösten et al., 1999), the top soil and subsoil textures were used to assign the Shetran soil parameters (porosity, residual moisture content, van Genuchten pa- rameters and saturated hydraulic conductivity). There is little information available on the subsurface geology. Ge et al. (2008) provides some information for the soil and aquifer properties for the Tibetan Plateau and there is some information available for the Sichuan Basin (Li et al., 2007; Zhou and $\mathrm{Li}, 1992)$. Li et al. (2007) note that the surface sediments in the Sichuan Basin can produce an unconfined aquifer. Due to these uncertainties, where there is a subsoil, an aquifer is assumed within the model. The depth and hydraulic conductivity of the aquifer was calibrated, with the calibration carried out to produce a baseflow that corresponds with the measured discharges. A hydraulic conductivity value of $15 \mathrm{~m} \mathrm{day}^{-1}$ for a $4 \mathrm{~m}$ deep aquifer produced the best fit.

Snow accumulation depends on both precipitation and air temperature with snowmelt calculated using a degree-day method (as there were insufficient data to use the more complex energy budget methods) with the melt dependent on the sum of the positive air temperatures. Hock (2003) reviewed values for a variety of sites around the world, and a typical value for snow of $3.5 \mathrm{~mm}$ day ${ }^{-1}{ }^{\circ} \mathrm{C}^{-1}$ was used here. Glaciers were not considered in this work, as they make up less than $0.1 \%$ of the catchment (Immerzeel et al., 2010).

The remaining parameters that were calibrated were the Strickler overland flow coefficient (1.0) and the Strickler flow coefficient for the river channels (50.0). These affect the speed of surface water flow and thus the shape of the hydrograph. A complete list of the calibrated parameters can be seen in Table 2.

A large number of dams exist within the Yangtze River basin upstream of the TGD (Yang et al., 2006). Due to the number of dams and the lack of knowledge of their operating procedures, the dams are not simulated. However, with the large wet season precipitation totals, the dams seem to have little effect on the discharge at Yichang (see Sect. 3.1).

A standard split sample calibration/validation was carried out for the Shetran simulation. The manual calibration was for 1996-2000 and the validation period for 20012005. The comparison between measured and simulated discharge is made using the Nash-Sutcliffe efficiency (NSE). All the Shetran input and result files are available in Birkinshaw (2017).

\subsection{CMIP5}

We use outputs from atmosphere-ocean general circulation models (GCMs) from the fifth phase of the Climate Model Intercomparison Project (CMIP5) under RCP8.5. RCP8.5 has a rising pathway of radiative forcing of more than $8.5 \mathrm{~W} \mathrm{~m}^{-2}$ in 2100 (more than $1370 \mathrm{ppm} \mathrm{CO}_{2}$ eq) (Moss et al., 2010). Sanderson et al. (2011) showed that RCP8.5 is similar to SRES A1FI (Nakićenović et al., 2000) and, although it is the highest emission scenario available in CMIP5, it still assumes emissions well below what the current energy mix would produce in the future. 
Table 1. Vegetation parameters used in the Shetran simulations of Yangtze.

\begin{tabular}{lrcc}
\hline Vegetation type & $\begin{array}{r}\text { Ground coverage } \\
\text { fraction }\end{array}$ & $\begin{array}{c}\text { Canopy storage } \\
\text { capacity (mm) }\end{array}$ & $\begin{array}{c}\text { Actual/potential } \\
\text { evapotranspiration }\end{array}$ \\
\hline Cropland & $0.01-1.0$ & 1.5 & 0.8 \\
Shrub/herbaceous & $0.01-0.8$ & 1.0 & 0.6 \\
Evergreen forest & $0.5-1.0$ & 3.0 & 1.0 \\
Deciduous forest & $0.1-1.0$ & 3.0 & 1.0 \\
Bare rock/soil & 0.0 & 0.2 & 0.5 \\
Rice paddies & $0.01-1.0$ & 1.5 & 0.8 \\
Lake/wetlands & 0.0 & 0.0 & 1.0 \\
\hline
\end{tabular}

${ }^{1}$ The ground coverage fraction varies seasonally. ${ }^{2}$ The actual/potential evapotranspiration is the value at field capacity it reduces as the soil dries (this parameter was calibrated).

Table 2. List of parameters calibrated in the Shetran model during the calibration period (1996-2000). If there is no subsurface soil (see Sect. 2.2), then an aquifer is not included in the model. The Strickler coefficient is the inverse of the Manning coefficient.

\begin{tabular}{llr}
\hline Parameter & Value & $\begin{array}{r}\text { Calibration } \\
\text { range }\end{array}$ \\
\hline Actual/potential evapotranspiration for each vegetation type & See Table 1 & $0.4-1.0$ \\
Aquifer depth $(\mathrm{m})$ & 4 & $0-20$ \\
Aquifer conductivity $\left(\mathrm{m} \mathrm{day}^{-1}\right)$ & 15 & $1-100$ \\
Strickler overland flow coefficient $\left(\mathrm{m}^{1 / 3} \mathrm{~s}^{-1}\right)$ & 1 & $0.2-5$ \\
Strickler flow coefficient for river channels $\left(\mathrm{m}^{1 / 3} \mathrm{~s}^{-1}\right)$ & 50 & $20-100$ \\
\hline
\end{tabular}

Since no "general all-purpose metric" to identify the best models exists (Knutti et al., 2010), we used all 78 CMIP5 runs for long-term simulations under RCP8.5, available at http://climexp.knmi.nl at the time of download, that contained both precipitation and air temperature(Birkinshaw, 2017). Table 3 details these experiments from 35 different GCMs, with several runs available for some of them. The downloaded CMIP5 outputs had been previously regridded and data were available for 21 grids $\left(2.5^{\circ}\right.$ by $\left.2.5^{\circ}\right)$ within the Yangtze Basin (shown in Fig. 1).

Due to their coarse resolution and inability to resolve significant subgrid-scale features, downscaling of GCM outputs is needed to assess local/regional impacts of climate change (Fowler et al., 2007). We use the simplest method: the change factor $(\mathrm{CF})$, perturbation or delta change approach where the mean change between control and future GCM outputs is applied to daily observations (by adding or multiplying, depending on the variable in question). We analysed changes in precipitation and air temperature between 1981-2010 and 2041-2070 from 21 GCM grid cells over the Yangtze for each of the 78 CMIP5 runs, extracted monthly change factors (ratio for precipitation, absolute for temperature) and modified the observed time series data (64 precipitation stations and 90 temperature stations) using the monthly $\mathrm{CF}$ from the nearest CMIP5 grid cell. There were 10 years of original data, so the procedure gives 10 years of future precipitation and temperature data.
A CF method was also used to obtain future PET. PET for both historical and future periods was calculated from climate model temperature outputs using the Thornthwaite equation. With this, PET change factors for each CMIP5 model run and each grid were calculated (similar to the precipitation procedure). These CFs were then applied to the observed PET.

PET is a theoretical concept with inherent direct monitoring difficulties; several equations have been developed to calculate PET from measurable variables. The reasons for using the Thornthwaite equation are considered in Sect. 4.2.

\section{Results}

\subsection{Historical data}

Figure 4a shows the excellent match between the Shetransimulated and measured daily discharge at Yichang for monthly values from 1996 to 2005 . The annual cycle of low discharges during the dry season (December to March), then increasing discharges up to July and then a gradual decrease back to December is well captured by the model, with only small differences between the measured and simulated values. The other plots in Fig. 4 compare measured and simulated mean daily discharges for 2 years of data. The daily discharge has a NSE of 0.95 for the calibration period (1996-2000) and 0.92 for the validation period (20012005). These NSE values are considerably higher than the 
Table 3. CMIP5 model runs. The results from 78 runs simulated using 35 GCMs are shown; if a model has several different runs, the number of runs and the ranges are shown in brackets. The summer monsoon results are from McSweeney et al. (2015). The performance is based on the ability of the GCMs to reproduce large-scale circulation flow at $850 \mathrm{hPa}$ for the Asian summer monsoon and is identified as "satisfactory" (green), "biases" (yellow), "significant biases" (orange) and "implausible" (red). If the analysis was not carried out by McSweeney et al. (2015), it is shown in grey. The future changes in precipitation and temperature are calculated in this study for the Yangtze Basin.

\begin{tabular}{|c|c|c|c|}
\hline Model & Summer monsoon & $\begin{array}{r}\text { Future change } \\
\text { in precipitation } \\
(\%)\end{array}$ & $\begin{array}{r}\text { Future change } \\
\text { in temperature } \\
\left({ }^{\circ} \mathrm{C}\right)\end{array}$ \\
\hline ACCESS1-0 & & 9.8 & 3.13 \\
\hline ACCESS1-3 & & 8.2 & 2.71 \\
\hline bcc-csm1-1 & & 1.4 & 2.39 \\
\hline BNU-ESM & & -0.4 & 2.78 \\
\hline CanESM2 (5) & & $\begin{array}{r}12.7 \\
(9.8-14.9)\end{array}$ & $\begin{array}{r}3.05 \\
(3.05-3.45)\end{array}$ \\
\hline CCSM4 (6) & & $\begin{array}{r}6.5 \\
(-0.5-6.5)\end{array}$ & $\begin{array}{r}2.49 \\
(2.32-2.54)\end{array}$ \\
\hline CESM1-BGC & & 6.4 & 2.34 \\
\hline CESM1-CAM5 (3) & & $\begin{array}{r}10.9 \\
(10.9-14.3)\end{array}$ & $\begin{array}{r}2.93 \\
(1.56-2.96)\end{array}$ \\
\hline CMCC-CM & & 1.0 & 2.71 \\
\hline CMCC-CMS & & 3.4 & 2.91 \\
\hline CNRM-CM5 (5) & & $\begin{array}{r}2.8 \\
(2.3-6.7)\end{array}$ & $\begin{array}{r}2.13 \\
(1.82-2.13)\end{array}$ \\
\hline CSIRO-Mk3-6-0 (10) & & $\begin{array}{r}-3.1 \\
(-3.5-2.8)\end{array}$ & $\begin{array}{r}2.85 \\
(2.65-2.87)\end{array}$ \\
\hline EC-EARTH (4) & & $\begin{array}{r}0.1 \\
(0.1-4.5)\end{array}$ & $\begin{array}{r}2.24 \\
(2.12-2.24)\end{array}$ \\
\hline FGOALS_g2 & & -0.1 & 2.24 \\
\hline FIO-ESM (3) & & $\begin{array}{r}-3.5 \\
(-3.5-3.0)\end{array}$ & $\begin{array}{r}2.57 \\
(1.68-2.57)\end{array}$ \\
\hline GFDL-CM3 & & 8.0 & 1.67 \\
\hline GFDL-ESM2G & & 3.6 & 3.69 \\
\hline GFDL-ESM2M & & -0.5 & 1.89 \\
\hline GISS-E2-H (p1-p3) & & $\begin{array}{r}0.6 \\
(0.6-2.3)\end{array}$ & $\begin{array}{r}2.08 \\
(2.08-2.78)\end{array}$ \\
\hline GISS-E2-R (r1-r3) & & $\begin{array}{r}-1.3 \\
(-1.6-4.6)\end{array}$ & $\begin{array}{r}2.75 \\
(2.27-2.75)\end{array}$ \\
\hline HadGEM2-AO & & 13.6 & 2.68 \\
\hline HadGEM2-CC & & 7.5 & 2.64 \\
\hline HadGEM2-ES (4) & & $\begin{array}{r}6.2 \\
(5.6-8.1)\end{array}$ & $\begin{array}{r}3.51 \\
(3.15-3.51)\end{array}$ \\
\hline inmem4 & & -1.2 & 3.25 \\
\hline IPSL-CM5A-LR (4) & & $\begin{array}{r}2.8 \\
(2.2-4.1)\end{array}$ & $\begin{array}{r}1.65 \\
(1.65-3.54)\end{array}$ \\
\hline IPSL-CM5A-MR & & -2.7 & 3.58 \\
\hline IPSL-CM5B-LR & & 1.9 & 3.44 \\
\hline MIROC5 (3) & & $\begin{array}{r}12.4 \\
(12.0-12.4)\end{array}$ & $\begin{array}{r}2.19 \\
(2.19-2.94)\end{array}$ \\
\hline MIROC-ESM & & 9.0 & 2.85 \\
\hline MIROC-ESM-CHEM & & 6.9 & 3.29 \\
\hline MPI-ESM-LR (3) & & $\begin{array}{r}-0.8 \\
(-0.8-0.6)\end{array}$ & $\begin{array}{r}3.68 \\
(2.60-3.68)\end{array}$ \\
\hline MPI-ESM-MR & & 3.4 & 2.73 \\
\hline MRI-CGCM3 & & 0.3 & 2.60 \\
\hline NorESM1-M & & 4.7 & 2.24 \\
\hline NorESM1-ME & & 6.0 & 2.55 \\
\hline
\end{tabular}



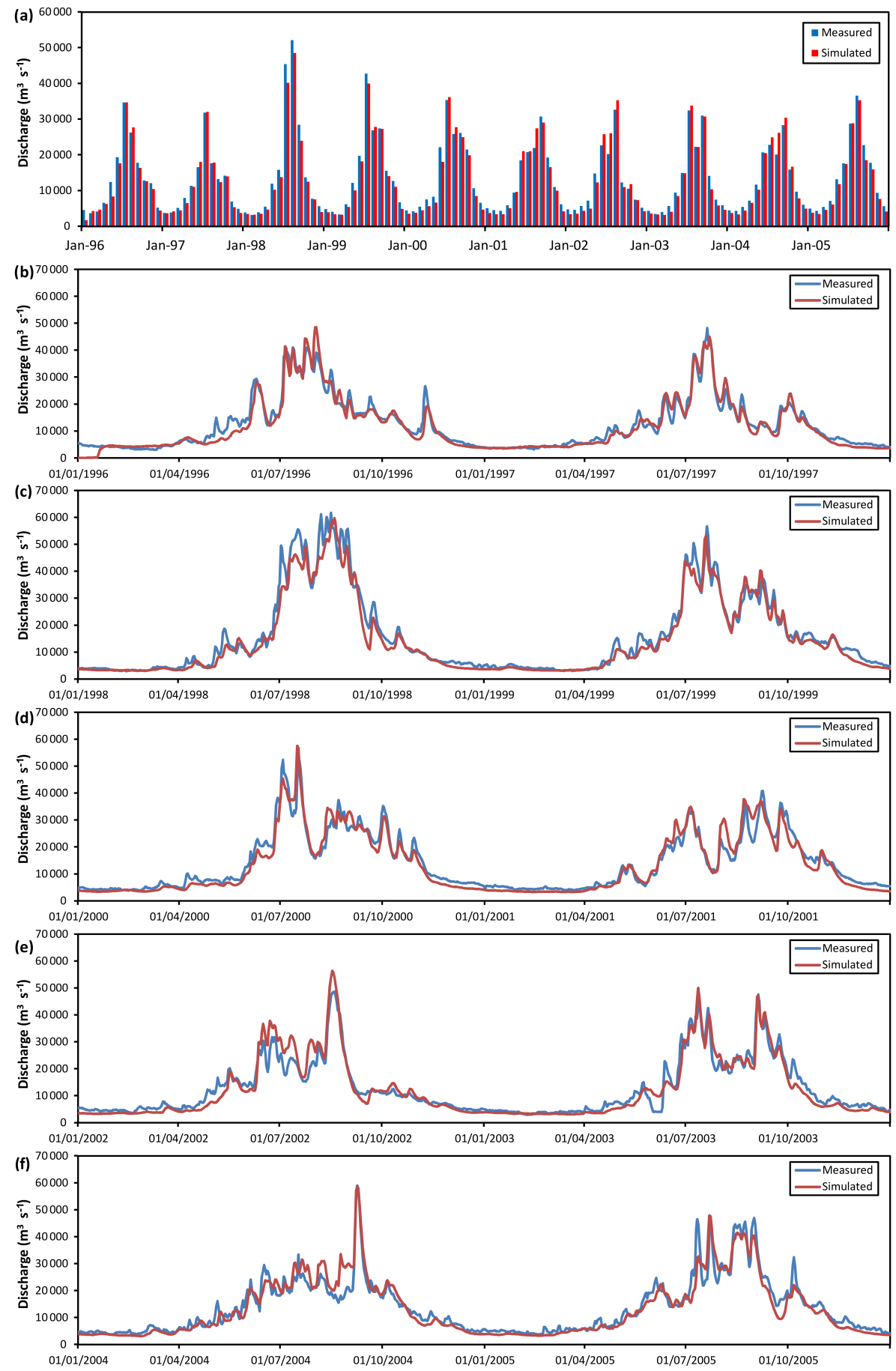

Figure 4. Measured and simulated daily discharges for the Yangtze at Yichang from 1996 to 2005. Panel (a) shows monthly averages and (b-e) show daily averages for 2-year periods.

value of 0.75 suggested by Moriasi et al. (2007) to classify the simulation as "very good". As well as using a $10 \mathrm{~km}$ by $10 \mathrm{~km}$ grid, Shetran simulations were carried out using both a $20 \mathrm{~km} \times 20 \mathrm{~km}$ grid and a $40 \mathrm{~km} \times 40 \mathrm{~km}$ grid. The results for coarser grid resolutions were less good, with overall (1996-2005) NSEs of 0.79 and 0.66 , respectively. This was mainly due to a poorer connectivity between the land surface grid squares and the river channels resulting in a much smoother hydrograph, with the simulated peak also occurring later than the measured peak. The results are also better than other models of the Yangtze Basin with a coarser grid resolu- 


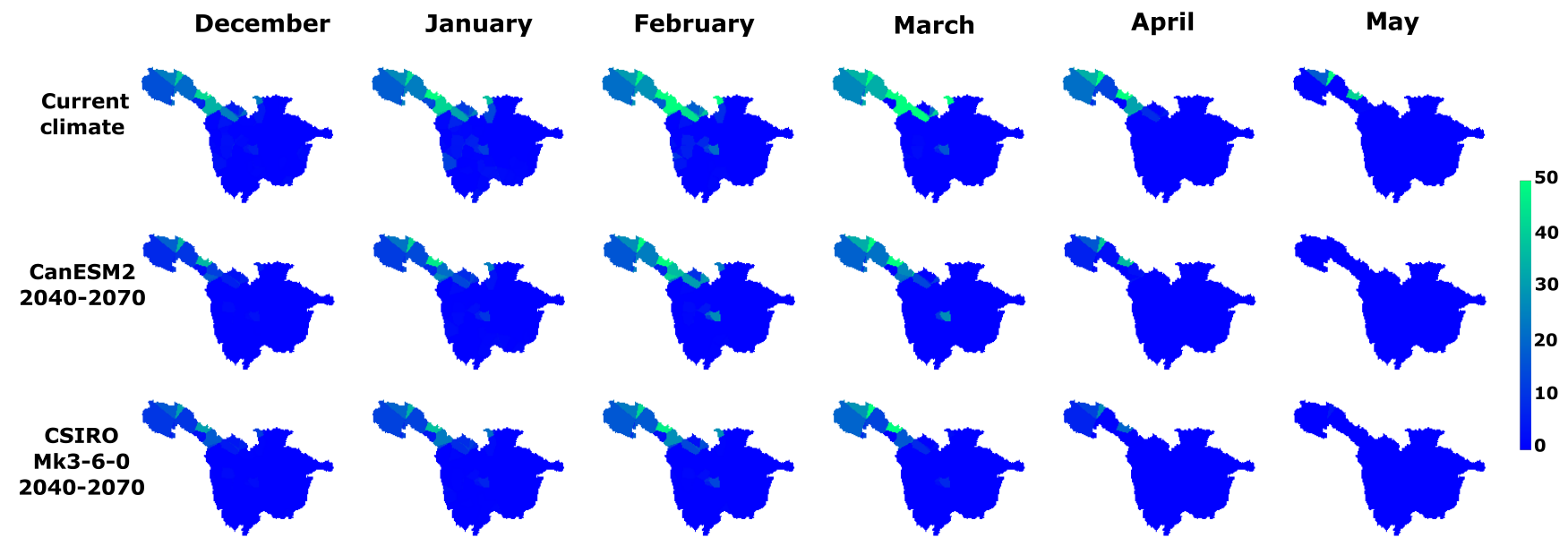

Figure 5. Simulated snow water equivalent depths $(\mathrm{mm})$ at the end of the months from December to May for the current climate and two future climate models.

tion. Woo et al. (2009)'s SLURP model gives a NSE of 0.83 and Xu et al. (2008)'s GBHM model gives a NSE of 0.85 .

Figure $4 \mathrm{e}$ shows an obvious reduction in discharge at Yichang from 26 May 2003 to 12 June 2003. This reduction was due to the first impoundment of water in the dam, with the water level at the TGD increasing from 65 to $135 \mathrm{~m}$ a.s.l. (Wang et al., 2013). After this, the water level remained fairly constant until the next impoundment in September 2006 (Wang et al., 2013). Therefore, as expected, the analysis of the discharge data at Yichang shows no obvious reduction for the rest of 2003-2005.

Accumulation of snow in the winter is a significant process in approximately $25 \%$ of the catchment (above around $3000 \mathrm{~m}$ in the north of the basin and $4500 \mathrm{~m}$ in the south of the basin); there are occasional snow falls in other parts of the basin. This can be seen in Fig. 5a which shows the monthly accumulations at the end of the month from December to May over the 10-year simulation. On average, the maximum snow water equivalent depth is $50 \mathrm{~mm}$ at the end of March. The totals are slightly lower in the Tibetan Plateau, as the winter precipitation totals are lower than for the area further east. Over the entire basin, the spatially averaged snow water equivalent depth is $6.6 \mathrm{~mm}$ at the end of March compared to a spatially averaged precipitation of $29 \mathrm{~mm}$ and an annual precipitation total of $904 \mathrm{~mm}$. As significant snow accumulation takes place during the dry part of the year in the drier part of the Yangtze Basin, the effect of snow accumulation and melt on discharge at Yichang is less than what might be expected from considering just the temperature within the basin. Within the model, the simulated snow accumulation and melting depend only on the precipitation and temperatures calculated for each grid square using a Thiessen polygon approach. Precipitation and temperature are considered to be uniform within each polygon. The 90 temperature stations give a good representation of the spatial distribution of temperature in the basin. Where there are sparse data in the Tibetan Plateau, there is a small range of elevations.

\subsection{Ability of the CMIP5 model runs to capture the current climate}

The ability of GCMs used in this work (Table 3) to capture the overall dynamics of the Asian summer monsoon is beyond the scope of this paper but work has previously been carried out by other researchers (Sperber et al., 2013; Song and Zhou, 2014; McSweeney et al., 2015; Dong et al., 2016). In the second column of Table 3, we reproduce results from McSweeney et al. (2015) to indicate the performance of the GCMs at reproducing large-scale circulation flow at $850 \mathrm{hPa}$ for the Asian summer monsoon. This flow is largely westerly across peninsular India before diverting to a south-westerly flow across the Bay of Bengal and then to a westerly flow across continental south-east Asia. The colours are "satisfactory" (green), "biases" (yellow), "significant biases" (orange) and "implausible" (red), and the grey colour means the model was not available to McSweeney et al. (2015). The "implausible" models have an unrealistic representation of the largescale flows of the monsoon and those with "biases" are not able to reproduce the strength of flows.

In Fig. 6, we consider model-simulated precipitation in more detail. Figure 6a shows the large spread in annual precipitation amongst the models and that all CMIP5 model runs overestimate annual observed precipitation. The IPSLCM5A-MR model is closest to the observed with a 30-year mean annual precipitation of $960.6 \mathrm{~mm}$, and the worst is the BNU-ESM model with $1919.5 \mathrm{~mm}$. In general, the models capture the spatial variation in precipitation reasonably well (Fig. 6b), with the lowest totals in the Tibetan Plateau and higher precipitation near the TGD, but given that the annual totals are too high, the totals in each percentile are also too high. The spatial variability of precipitation in MIROC-ESM 

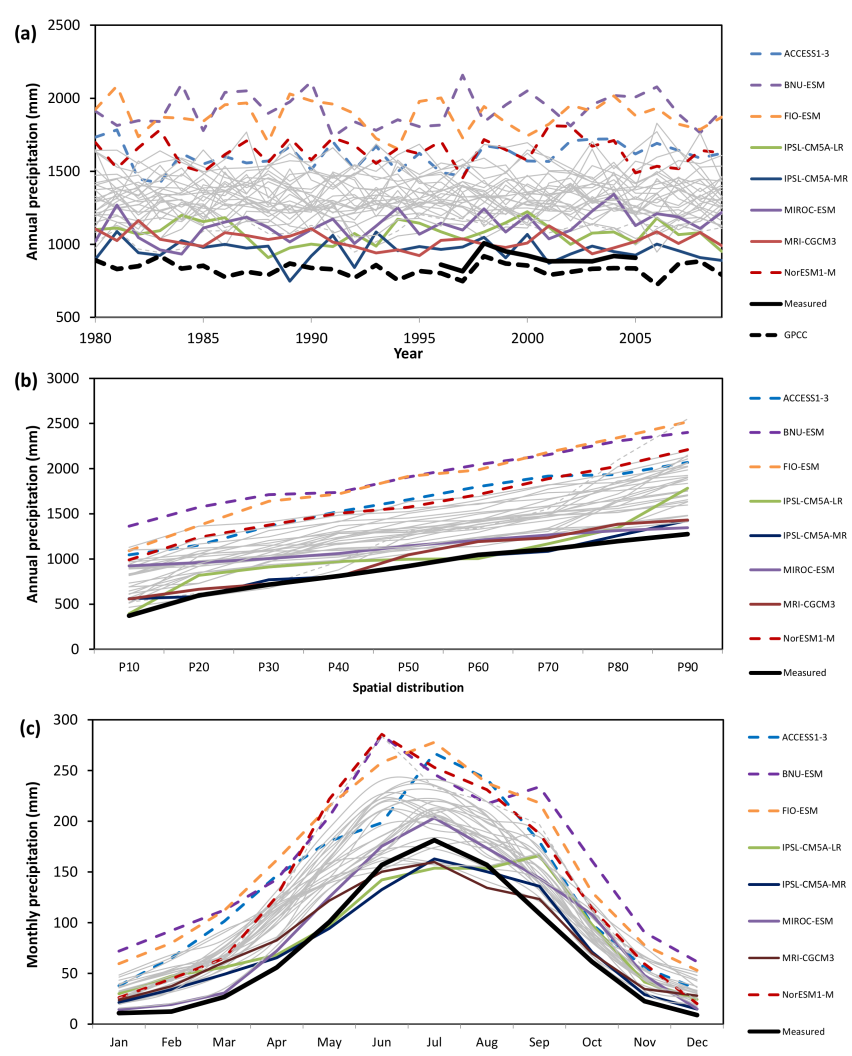

Figure 6. Comparison of the measured and CMIP5 climate models for the precipitation in the Yangtze Basin. The data from each GCM are shown, but only the four with the largest and smallest totals are in colour; the rest are shown in grey. Panel (a) shows the annual precipitation (measured Global Precipitation Climate Centre (GPCC) data are also shown), (b) the spatial distribution across the Yangtze Basin showing the 10th-90th percentiles and (c) the intraannual distribution.

and MIROC-ESM-CHEM is poor, estimating nearly as much precipitation in the drier regions as in the wetter regions of the basin. Considering the annual variation in precipitation (Fig. 6c), the CMIP5 models give a multimodel ensemble average larger than the measured average throughout the year. However, the fractional increase is much smaller in the wet season, which is similar to that found by Chen and Frauenfeld (2014; Fig. 5).

The results in Fig. 7 indicate that all CMIP5 GCMs underestimate observed mean annual temperature in the Yangtze Basin $\left(10.2{ }^{\circ} \mathrm{C}\right)$. The MIROC5 model produces the best estimate, with a mean temperature of $7.3^{\circ} \mathrm{C}$, and the worst is the CNRM-CM5 model with a mean value of $2.6^{\circ} \mathrm{C}$. However, all models satisfactorily reproduce the observed spatial distribution and seasonality of temperature.

\subsection{Future changes}

A majority of CMIP5 model runs (59 of the 78 models) predict increases in annual precipitation, with a smaller num-
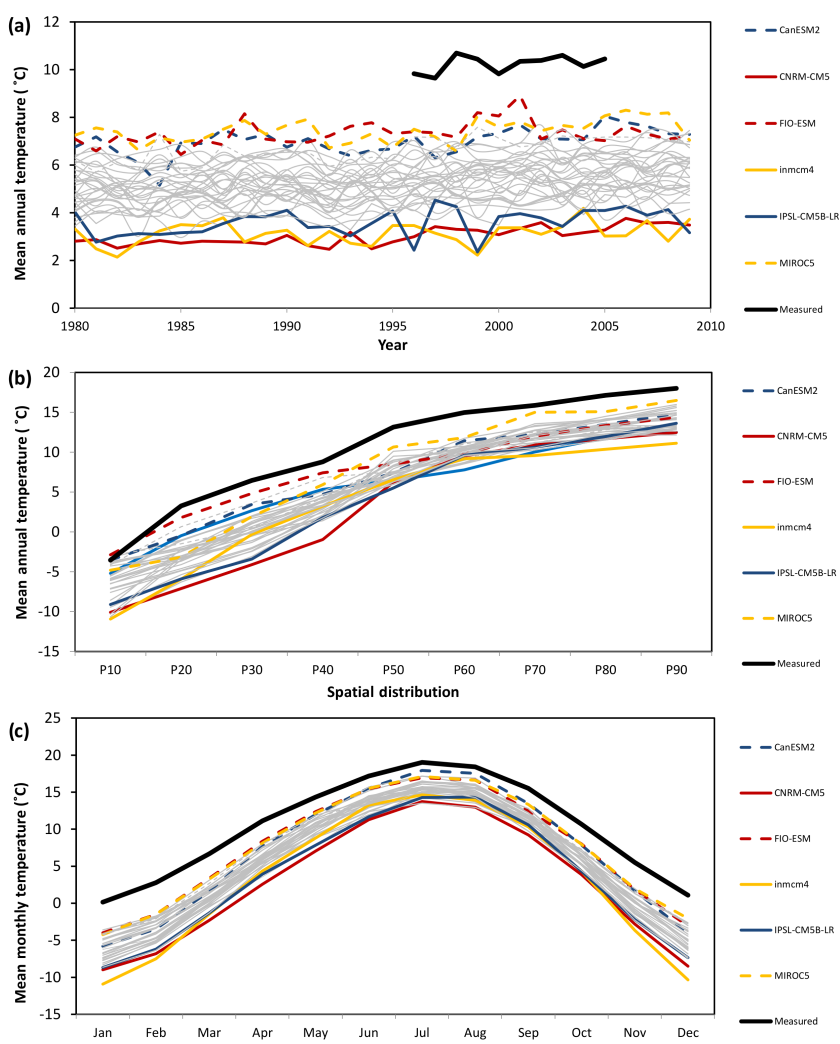

Figure 7. Comparison of the measured and CMIP5 climate models for the temperature in the Yangtze Basin. The data from each GCM are shown, but only the three with the largest and smallest temperature biases are in colour; the rest are shown in grey. Panel (a) shows the annual precipitation, (b) the spatial distribution across the Yangtze Basin showing the 10th-90th percentiles and (c) the intra-annual distribution.

ber (19) predicting decreases (Table 3). Applying the nonparametric Kolmogorov-Smirnov (KS) test at the 0.05 significance level indicates 44 models with a statistically significant increase in precipitation and 34 with no significant change. All the model runs predict statistically significant increases in temperature and PET.

Considering the months separately, Fig. 8 shows box plots of the spatially averaged changes in precipitation, temperature and PET. Most models project increases in precipitation for all months, which can reach up to $40 \%$, but some models project decreases in precipitation in some months. All models project increases in temperature in every month but this varies between just over $1{ }^{\circ} \mathrm{C}$ to more than $4{ }^{\circ} \mathrm{C}$. Using the Thornthwaite equation, changes in PET are relatively small in winter because of the very low temperatures (mean December-February temperature is $-5^{\circ} \mathrm{C}$ ). However, in summer, the projected increases in PET are larger, with some models projecting increases up to $25 \mathrm{~mm}$. 


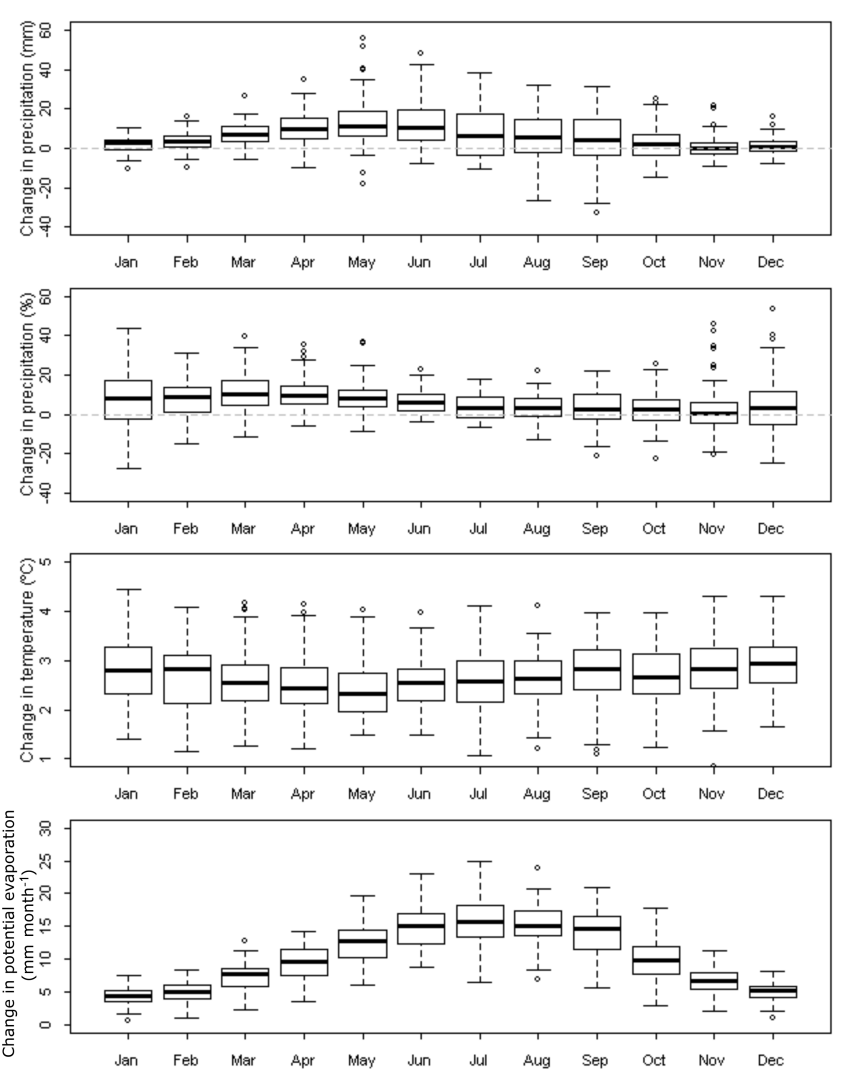

Figure 8. Box plots showing monthly changes between 1981-2010 and 2041-2070 in precipitation, temperature and potential evaporation for the 78 CMIP5 runs averaged over the Yangtze Basin.

Figure 9 shows box plots of annual changes in precipitation, temperature and PET for the different CMIP5 grid cells (i.e. the spatial variation). Most models project an annual increase in precipitation for all CMIP5 grid cells. Considering the median values and the percentage change in precipitation (Fig. 9b), the high and dry areas of the Tibetan Plateau (grid cells 1,2 and 3 ) show the biggest increases $(10.8,8.6$ and $9.4 \%$ ) and the areas furthest south (grid cells 7,11 and 15) show the smallest increases $(2.8,0.91$ and $1.4 \%)$. However, the projections show a wide range, with individual models indicating both increases and decreases in annual precipitation in all areas of the basin. Considering the change in precipitation (Fig. 9a), the range of possible changes from CMIP5 is largest in the south-western part of the basin (grids 4, $7,8,11$ and 12), and this uncertainty will have an important effect on the future volume of discharges in the Yangtze River at the TGD. The high-altitude areas (grids 1, 2, 3, 5, 6,9 and 10) show the largest temperature increases (Fig. 9c) but, due to their current low temperatures, small increases in PET (Fig. 9d). Accordingly, the warmer eastern areas show a higher increase in PET, as a $2{ }^{\circ} \mathrm{C}$ rise in air temperature has a larger effect at higher temperatures.

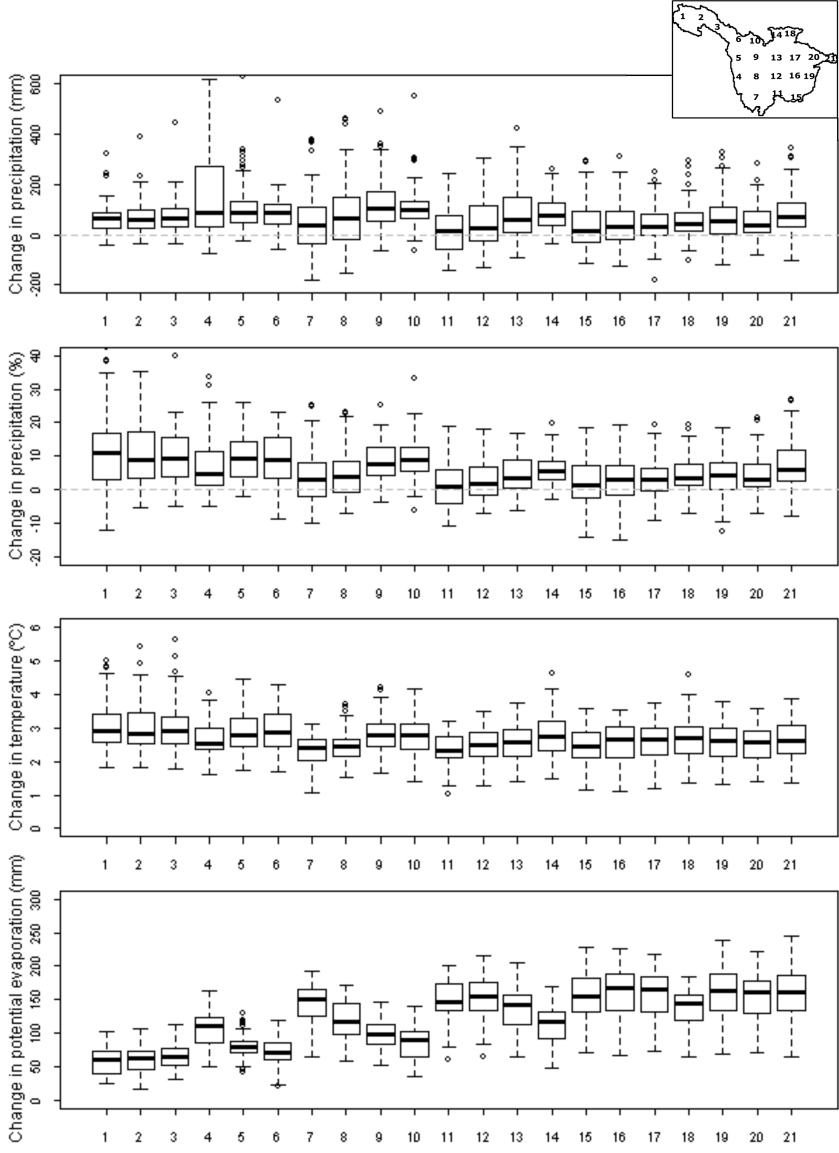

Figure 9. Box plots showing spatial changes between 1981-2010 and 2041-2070 in precipitation, temperature and potential evaporation for the 78 CMIP5 runs. The numbers on the $x$ axis correspond to the $2.5^{\circ}$ by $2.5^{\circ}$ CMIP5 grids numbered in Fig. 1 and shown in the inset.

Figure 10a shows box plots of future projections (20412070) for the basin's annual average precipitation, PET, simulated discharge and simulated actual evapotranspiration from the 78 CMIP5 runs. The blue squares show the simulated values for the present climate. Most model runs project increases in precipitation and all models show an increase of potential and, consequently, actual evapotranspiration (since water availability during the warm season is not an issue). These two factors combined mean that the spread of future discharge projections for the annual totals encompass the present conditions, with 11 model runs showing an increase and 67 a decrease in annual discharge.

Future discharge projections for individual months for all 78 future climate runs are shown as box plots in Fig. 11, with the current climate shown as a blue square. Current discharges are encompassed in the intermodel spread for the future for all months. However, most models show a decrease in discharge in every month compared to the current climate, with the largest decreases in the wet season. A reduction in discharge early in the wet season would affect agricultural 

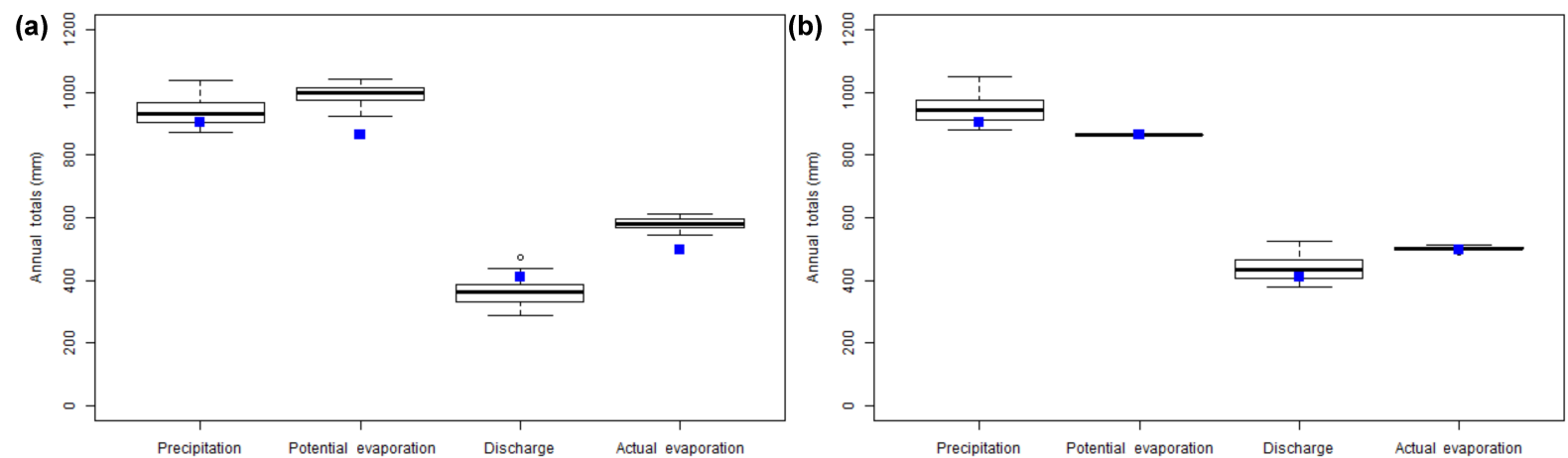

Figure 10. Box plot showing the range of precipitation, potential evaporation, simulated discharge and simulated actual evaporation over the 78 CMIP5 future climates. Panel (a) indicates PET calculated using the Thornthwaite equation and (b) indicates no change in PET. The blue squares show the simulated values for the present climate.

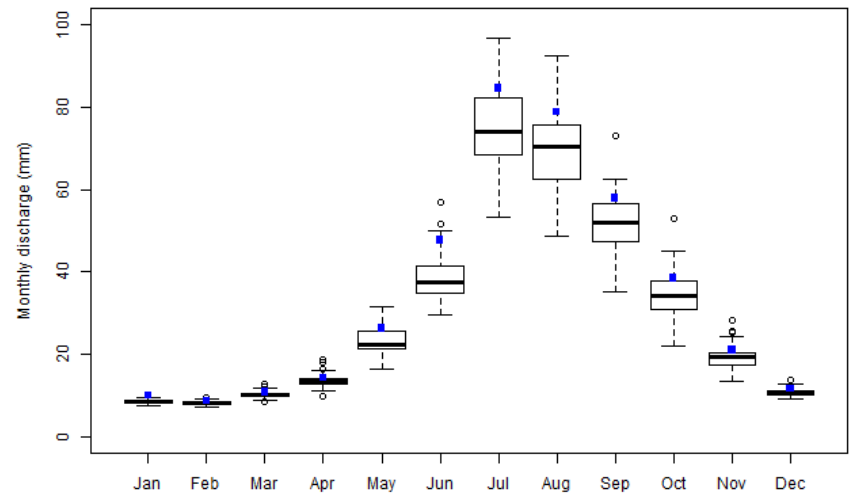

Figure 11. Box plots for individual months showing the range of simulated discharges over the 78 CMIP5 future climates. The simulated discharge for the current climate for each month is shown by the blue square.

production within the Yangtze Basin and a reduction in discharge late in the wet season (September and October) would affect hydropower production in the dry season at TGD, since these are particularly important months for filling its reservoir. The largest reduction in projected discharge is in June (with 72 models showing a decrease in discharge and 6 showing an increase), partly due to changes in snow accumulation and melt. Figure 5 shows that by the end of May, under the present climate, there is still a significant amount of snow in the upper part of the basin, whereas for CanESM2 and CSIRO-Mk3-6- $0(+12.7$ and $-3.7 \%$ change in precipitation, respectively) all the remaining snow melts in May (note that there is a travel time of approximately 30 days for the water to flow from the upper part of the basin to Yichang). The modelling suggests that, under the present climate, $4.2 \mathrm{~mm}$ of June discharge at Yichang is from snowmelt; this reduces to $2.2 \mathrm{~mm}$ for the median of the CMIP5 simulations. June discharge is also affected by higher evapotranspiration in the CMIP5 simulations compared to the present-day climate, as the earlier snowmelt allows the evapotranspiration to start
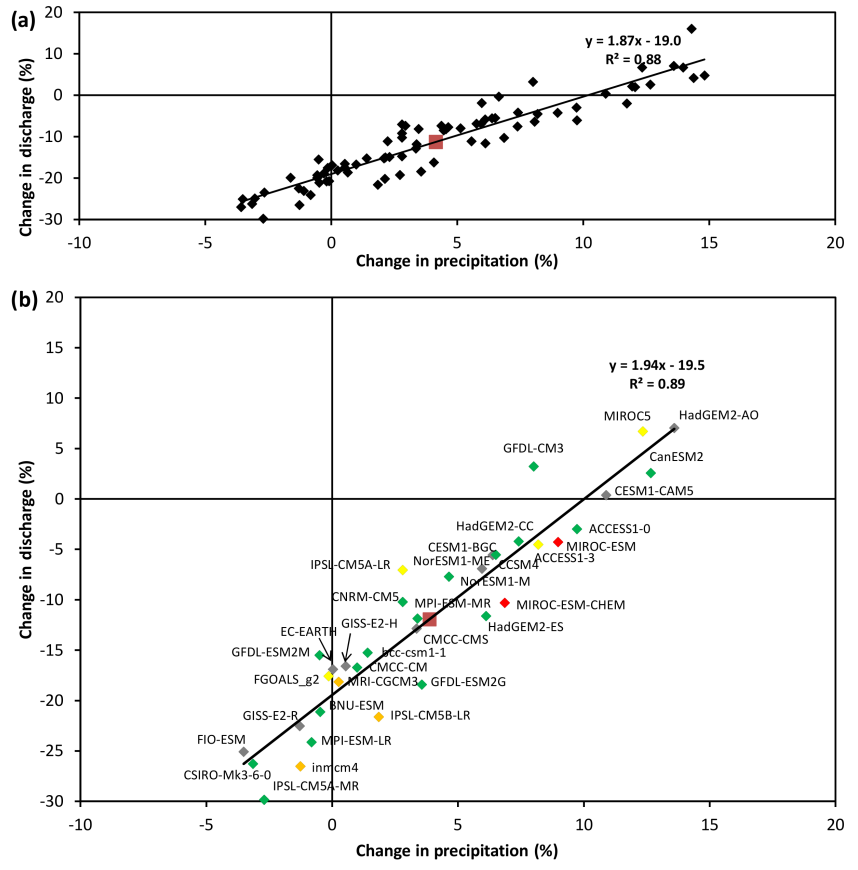

Figure 12. Change in simulated discharge and precipitation between the current and future climates: (a) for each of the 78 CMIP5 future climate projections and (b) for each of the 35 GCM models (labelled). The colours correspond to those produced by McSweeney et al. (2015) in Table 3 for the summer monsoon whereby green is "satisfactory", yellow "biases", orange "significant biases", red "implausible" and grey models are where the data were not available.

earlier (the snow covering the vegetation prevents any evapotranspiration).

We plot the change in both precipitation and simulated discharge between current and future projections for each of the 78 CMIP5 runs in Fig. 12a. The multimodel mean increase in precipitation is $4.1 \%$ which corresponds to an $11.1 \%$ decrease in discharge (shown by the red square). The 78 CMIP5 
runs show a large range of potential future outcomes: from a $3.6 \%$ drop to a $14.8 \%$ increase in precipitation and a $29.8 \%$ drop to a $16.0 \%$ increase in discharge. The slope of the fitted line through all 78 CMIP5 runs in Fig. 12a shows that a $10 \%$ change in precipitation produces, on average, an $18.7 \%$ change in annual discharge. The problem with this analysis is that some of the GCMs have multiple runs (e.g. CSIROMk3-6-0 has 10 runs), and these are not independent. Therefore, in Fig. 12b, the simulated discharge between current and future projections for each of the 35 GCMs are plotted (the individual models are also labelled). This shows very similar results, with a multimodel mean increase in precipitation of $3.9 \%$ which corresponds to an $11.9 \%$ decrease in discharge. The range of precipitation $(-3.5$ to $+13.6 \%)$ and discharge $(-29.8$ to $+7.0 \%)$ is slightly reduced. The colours in Fig. 12b correspond to those used by McSweeney et al. (2015) to assess the performance of models at reproducing the climate of the Asian summer monsoon (see Table 3). The "satisfactory" green points cover almost the entire range and so it is very hard to discount any future projections of change in precipitation or discharge (plotting only these points gives a very similar response and does not lead to a significantly lower spread of the ensemble of discharge projections).

\subsection{Comparison of the CanESM2 and CSIRO-Mk3-6-0 models}

To understand why there is such a large range in the future projections of discharge in the Yangtze Basin, two models were selected and analysed in more detail: CanESM2 and CSIRO-Mk3-6-0. Both models are able to represent the large-scale circulation of the Asian summer monsoon satisfactorily (McSweeney et al., 2015) and are two of the best models at simulating precipitation and temperature indices in the Yangtze Basin. However, although both models project similar increases in temperature, 3.05 and $2.85^{\circ} \mathrm{C}$, respectively, CanESM2 projects a $12.7 \%$ increase in precipitation and a $2.6 \%$ increase in discharge, whereas CSIRO-Mk3-6-0 projects a $3.1 \%$ decrease in precipitation and a $26.3 \%$ decrease in discharge. Figure 13a-c shows the annual, monthly and spatial precipitation variability over the Yangtze Basin in both models. Both show a slightly earlier onset of the summer monsoon (Fig. 13b) in a future climate but the key difference between the two can be seen in Fig. 13c, e and $\mathrm{f}$ which consider the distribution of precipitation across the CMIP5 grid cells. CanESM2 shows a very large increase in annual precipitation in grid $4(604 \mathrm{~mm})$ and also large increases of more than $250 \mathrm{~mm}$ in grid cells 5, 7, 8 and 9, whereas CSIRO-Mk3-6-0 projects no significant change or a slight reduction in precipitation in these grids. These spatial differences in precipitation produce the large difference in the projected discharge, seen for each month in Fig. 13d. Grid cells 4, 5, 7, 8 and 9 (Figs. 1 and 13e, f) are in the southwest part of the Yangtze Basin and, as shown in Fig. 9, show the greatest range in future projections across all the models. Thus, most of the variation in discharge across the different models is due to the change in precipitation seen across these grids in the south-west of the basin. This is considered further in Sect. 4.4.

\section{Discussion}

\subsection{Change factor approach}

In this paper, the $\mathrm{CF}$, perturbation or delta change approach was used to produce the future climate scenarios. The simplicity of this method makes it possible to downscale several GCMs/scenarios quickly but, on the other hand, it assumes that the GCM bias is constant and that variability, spatial patterns of climate and percentage of wet/dry days will remain constant (Fowler et al., 2007). However, this method does preserve the observed spatial correlations between stations or grid points, which some complex methods are not able to do, and it also captures the full climate signal of the GCM, while more complex downscaling methods capture only climate forcing shown by the chosen predictor(s) and grid box(es) (Diaz-Nieto and Wilby, 2005). The CF method is not suitable for the study of extreme events (since it does not take into consideration any changes to the variance and skewness of the precipitation). For small river basins, this might have significant consequences in the projected discharge; however, in a large river basin, such as the Yangtze, there is considerable attenuation of the hydrograph. Therefore, the consequences of changes in the precipitation variance and skewness on the basin's monthly mean discharges will be much smaller. Also, this is a widely used method that has been considered appropriate for studies where changes in average values, such as impacts on water resources, are relevant (Sunyer et al., 2010).

\subsection{Potential evapotranspiration (PET)}

There is still considerable debate about the best method for calculating PET under a changing climate using climate model outputs; see, e.g. Ekström et al. (2007); Kingston et al. (2009); Sperna Weiland et al. (2012); Prudhomme and Williamson (2013); McMahon et al. (2015); Milly and Dunne (2016). In this study, the Thornthwaite equation was chosen to calculate change factors because, although it is simplistic, it only requires temperature time series which is a fairly reliable GCM output. The Penman-Monteith method was not used, as it is based on variables that are not well simulated by GCMs, like cloud cover and vapour pressure (Kingston et al., 2009), and the results can be physically unrealistic (Ekström et al., 2007). However, this does mean that changes in PET as a result of changes in wind speed, cloud cover and vapour pressure deficit are not accounted for and Chen et al. (2006) and Yan et al. (2011) have shown the importance of these meteorological variables for PET from the Tibetan Plateau. McMahon et al. (2015) suggest that the ef- 

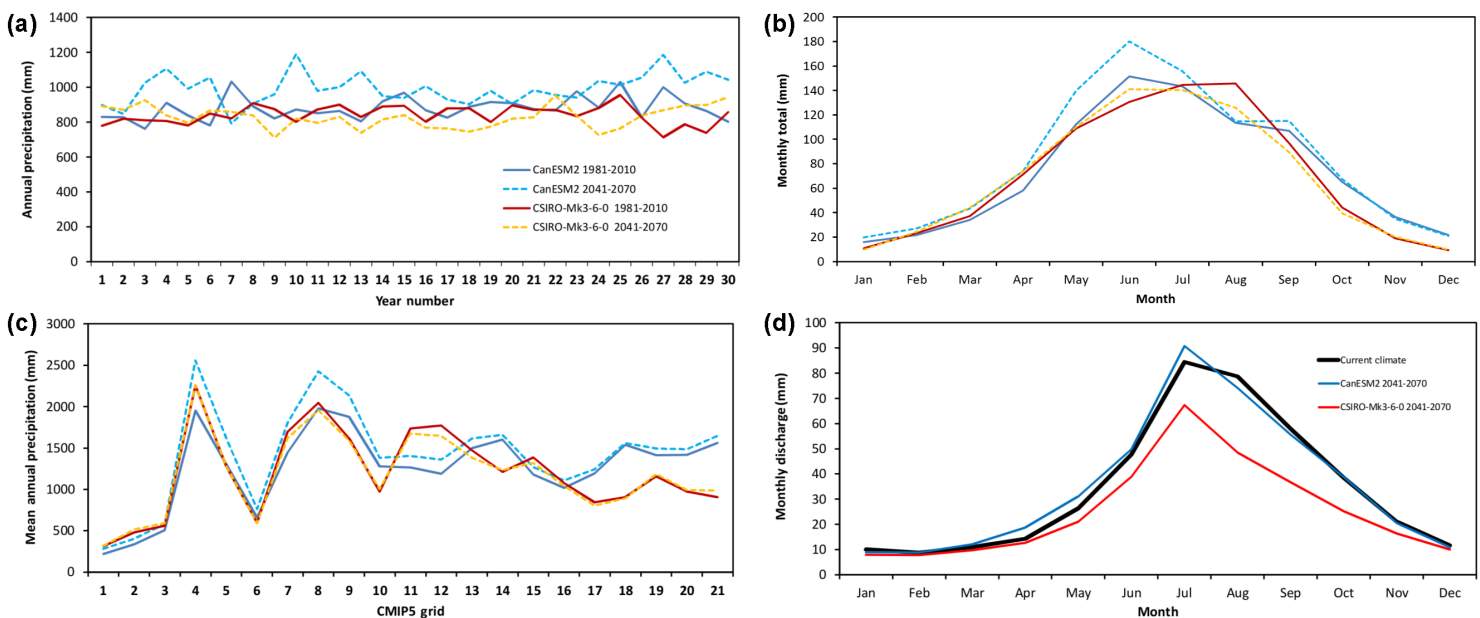

(e)
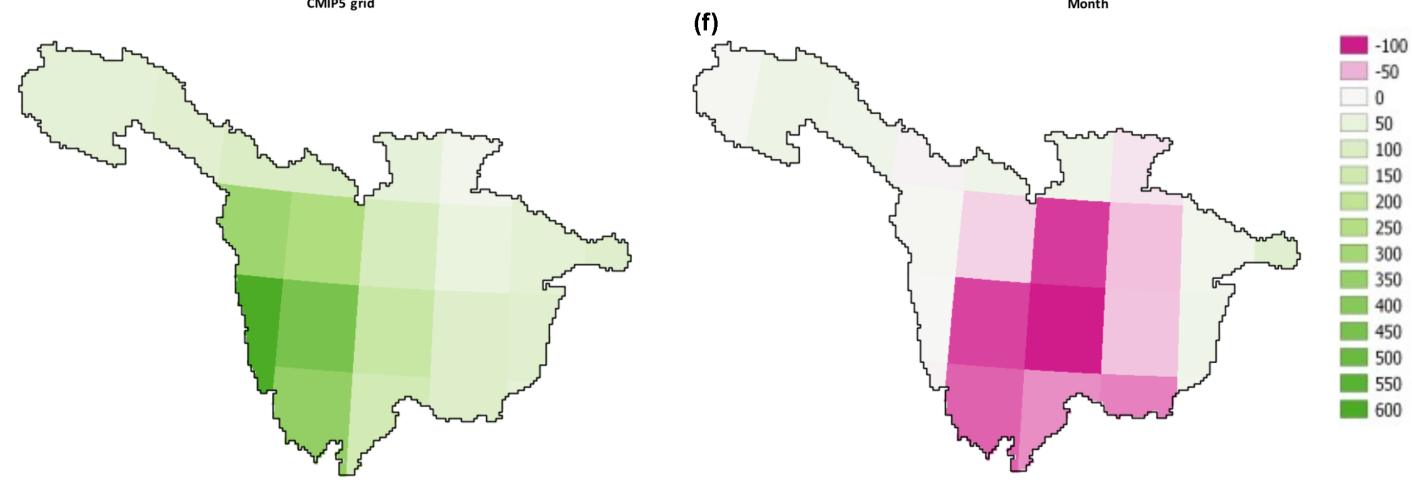

Figure 13. Comparison of the current climate and future climate projections for the CanESM2 model and the CSIRO-Mk3-6-0 model: (a) annual precipitation and (b) monthly precipitation fraction. (c) Mean annual precipitation for each $2.5^{\circ}$ by $2.5^{\circ} \mathrm{CMIP} 5$ grid numbered in Fig. 1. (d) Monthly discharge from using the Shetran hydrological model. (e) Change in mean annual precipitation for the CanESM2 model for each $2.5^{\circ}$ by $2.5^{\circ}$ grid. (f) Change in mean annual precipitation for the CSIRO-Mk3-6-0 model for each $2.5^{\circ}$ by $2.5^{\circ}$ grid.

fect of using just temperature to calculate PET is likely to be most important in an energy-limited region such as the Tibetan Plateau but is less important in other regions such as the rest of the Yangtze Basin.

Nevertheless, as a sensitivity test, the model experiments were run for a second time with no change to PET (i.e. the time series of 10 years of historic PET data were used together with the projected changes in precipitation and temperature). Figure 10b shows this produced an intermodel basin mean increase in discharge of $7.5 \%$ with a range between -7.6 and $+28.7 \%$. As expected, the discharges are significantly higher than those using future PET where the intermodel basin mean reduction in discharge was $11.1 \%$ with a range between -29.8 and $+16.0 \%$.

Further analysis was carried out by considering the change in actual evaporation from the 78 climate model projections. Averaged over the Yangtze Basin, this shows an increase of $8.4 \%$ under the future climate compared to a $17 \%$ increase in actual evaporation using the PET calculated from the Thornthwaite equation and a $1 \%$ increase in actual evaporation with no change in PET. This suggests the future ac- tual evaporation might be between the two extremes shown in Fig. 10a and b.

This analysis shows the importance of the changes in PET for future discharges and the need for future research on how to calculate realistic PET from climate model outputs.

\subsection{Limited measured data}

Only 10 years of meteorological data were used to calibrate and validate the hydrological model of the Yangtze, with the comparison of the measured and simulated discharge data showing that the Moriasi et al. (2007) "very good" criteria value was easily exceeded in every year. Ideally, a longer time series of measured meteorological and discharge data would be available so any annual extremes or interdecadal variation in precipitation can be captured by the model. To test the effects of using only 10 years of measured precipitation data, the areal averaged annual totals (from 64 stations) were compared against the Global Precipitation Climate Centre (GPCC) dataset. Gridded GPCC data are available for monthly precipitation at $0.5^{\circ} \times 0.5^{\circ}$ from 1901 to 2010 (Schneider et al., 2014) and are based on in situ obser- 
vations across global land areas. Figure 5a shows that precipitation totals from GPCC are consistently slightly lower than the data observations used in this study. However, both show similar interannual variability. In the 30-year GPCC record, there are no extremes of precipitation which are large outliers to the 10 years of precipitation observations used in this study.

Discharge simulations under future climate are uncertain because of uncertainties in future greenhouse gas emissions, climate models, downscaling methods and hydrological models. This study focuses on the uncertainty stemming from the climate models because of its significant influence on the uncertainty in discharge projections (e.g. Ragettli et al., 2013; Addor et al., 2014).

\subsection{Climate change}

Using 78 climate projections under RCP8.5 from the most recent generation of climate models (CMIP5), the analysis shows that between 1981-2010 and 2041-2070 projections of change to basin annual precipitation vary from -3.6 to $+14.8 \%$, with a multimodel mean of $4.1 \%$. This small increase in precipitation agrees with other analyses of projected changes to precipitation from both the previous generation of climate models (CMIP3) and the most recent ones (CMIP5) (Piao et al., 2010; Tao et al., 2012; Jiang and Tian, 2013; Tian et al., 2015).

However, in this study, we focus on the changes to discharge, using projections from 78 CMIP5 model runs together with a hydrological model. Overall, a multimodel basin mean reduction in discharge of $11.1 \%$ was projected for 2041-2070, with a range between -29.8 and $+16.0 \%$. The results suggest no agreement in the sign of change and a potentially large range of values.

The key to predicting future changes to discharge in the Yangtze Basin is correctly predicting how the strength and location of the summer monsoon will change under a future climate (the importance of predicting future changes in the PET was discussed in Sect. 4.2). Lee and Wang (2014) evaluated 20 CMIP5 models while considering future changes in the monsoon and selected the four best ones, which included the CanESM2 model. The four best models projected that the land monsoon domain over Asia will expand westward with a $10.6 \%$ increase in monsoon extent under the RCP4.5 scenario. However, we have shown that there is major uncertainty in this supposed expansion into the Yangtze Basin, as in some GCMs (e.g. CanESM2) there is an expansion of the monsoon domain north and west, and this increased precipitation produces an increase in the discharge, whereas, in most other GCMs (e.g. CSIRO-Mk3-6-0), there is not an expansion in the domain and so it results in a decrease in the discharge (due to greater evapotranspiration). Until the strength and location of the monsoon under a future climate can be reliably predicted, there will remain large uncertainty in changes to projected discharge for the Yangtze Basin.

\section{Conclusions}

Water resources, flooding and hydropower generation on the Yangtze River are all important due to the size of the population and the industry and agriculture it supports. Variability in the Yangtze discharge under a future climate is therefore of great concern. This study has, for the first time, taken 78 state-of-the-art climate model projections from CMIP5 (from 35 different GCMs) and used these together with a detailed hydrological model of the Yangtze Basin to estimate potential changes to future discharge.

We considered 78 CMIP5 projections for the Yangtze RCP8.5 and examined the change in precipitation between 1981-2010 and 2041-2070. The results showed a big spread, without agreement even in the sign of the change for both monthly and annual precipitation (from -3.6 to $+14.8 \%$ ). However, most GCMs projected an increase in precipitation for most months with a multimodel basin mean change of $+4.1 \%$. GCM projections for change in temperature for the same time period showed significant increases, which varied from just over $1^{\circ} \mathrm{C}$ to more than $4^{\circ} \mathrm{C}$. The changes in PET, calculated using the Thornthwaite equation, also showed significant increases.

The Shetran hydrological model gave an excellent match between measured and simulated discharge for the Yangtze River basin to Yichang $\left(1007200 \mathrm{~km}^{2}\right)$ with a NashSutcliffe efficiency of 0.95 for the calibration period in 19962000 and of 0.92 for the validation period from 2001 to 2005 . Using monthly change factors within the basin to modify the historic meteorological data, future climate scenarios were obtained for each of the 78 CMIP5 projections and applied to Shetran. These produced a multimodel basin mean change in discharge of $-11.1 \%$, with a range between -29.8 and $+16.0 \%$.

Overall, this work has highlighted the uncertainty in GCM-projected changes of precipitation and temperature and their effect on the discharge in the Yangtze Basin. In particular, it has highlighted the importance of predicting the strength and location of the summer monsoon. To fully understand the effect that climate change will have on the Yangtze Basin, there needs to be an improvement in climate model projections, in particular, of precipitation over the basin. Piao et al. (2010) came to a similar conclusion looking at the effect of climate change on agriculture in China.

Using a more process-based formulation of PET (e.g. Penman-Monteith) would improve the realism of the discharge projections. Further work is also needed to examine how changes in extreme precipitation can cause floods, and we intend to carry out future Shetran simulations using different downscaling techniques. 
Data availability. Data supporting this publication are openly available under an "Open Data Commons Open Database License". Additional metadata are available at doi:10.17634/120693-2 (Birkinshaw, 2017).

Competing interests. The authors declare that they have no conflict of interest.

Acknowledgements. This work was a result of the following funding projects: (1) 973 Program (grant no. 2013CB036401) and (2) UK EPSRC Global Secure project (EP/K004689/1). Hayley J. Fowler was supported by the Wolfson Foundation and the Royal Society as a Royal Society Wolfson Research Merit Award holder (WM140025). We acknowledge the World Climate Research Programme's Working Group on Coupled Modelling, which is responsible for CMIP, and thank the climate modelling groups for producing and making their model output available. We would also like to thank Geert Jan van Oldenborgh from the KNMI Climate Explorer website for making output from CMIP5 available in an easy-to-use and downloadable format. Finally, we would like to thank three anonymous reviewers for their valuable comments and suggestions.

Edited by: J. Seibert

Reviewed by: three anonymous referees

\section{References}

Addor, N., Rössler, O., Köplin, N., Huss, M., Weingartner, R., and Seibert, J.: Robust changes and sources of uncertainty in the projected hydrological regimes of Swiss catchments, Water Resour. Res., 50, 7541-7562, doi:10.1002/2014WR015549, 2014.

Bartholomé, E., Belward, A. S., Achard, F., Bartalev, S., CarmonaMoreno, C., Eva, H., Fritz, S., Grégoire, J.-M., Mayaux, P., and Stibig, H.-J.: GLC 2000, Global Land Cover mapping for the year 2000, European Commission, DG Joint Research Centre, EUR 20524, 2002.

Bathurst, J. C., Birkinshaw, S. J., Cisneros, F., Fallas, J., Iroumé, A., Iturraspe, R., Novillo, M. G., Urciuolo, A., Alvarado, A., Coello, C., and Huber, A.: Forest impact on floods due to extreme rainfall and snowmelt in four Latin American environments 2: Model analysis, J. Hydrol., 400, 292-304, 2011.

Birkinshaw, S. J.: Technical Note: Automatic river network generation for a physically-based river catchment model, Hydrol. Earth Syst. Sci., 14, 1767-1771, doi:10.5194/hess-14-17672010, 2010.

Birkinshaw, S. J., Bathurst, J. C., and Robinson, M.: 45 years of non-stationary hydrology over a forest plantation growth cycle, Coalburn catchment, Northern England, J. Hydrol., 519, 559573, doi:10.1016/j.jhydrol.2014.07.050, 2014.

Birkinshaw, S. J., James, P., and Ewen, J.: Graphical user interface for rapid set-up of SHETRAN physically-based river catchment model, Environ. Modell. Softw., 25, 609-610, doi:10.1016/j.envsoft.2009.11.011, 2010.
Birkinshaw, S.: Yangtze climate change data and Shetran simulation input files and results, Newcastle University, doi:10.17634/120693-2, 2017.

Breuer, L., Eckhardt, K., and Frede, H.-G.: Plant parameter values for models in temperate climates, Ecol. Model., 169, 237-293, doi:10.1016/S0304-38000300274-6, 2003.

Chen, L. and Frauenfeld, O. W.: A comprehensive evaluation of precipitation simulations over China based on CMIP5 multimodel ensemble projections, J. Geophy. Res.-Atmos., 119, 5767-5786, doi:10.1002/2013JD021190, 2014.

Chen, S., Liu, Y., and Thomas, A.: Climatic change on the Tibetan Plateau: potential evapotranspiration trends from 19612000, Climatic Change., 76, 291-319, doi:10.1007/s10584-0069080-z, 2006.

Dai, H., Cao, G., and Su, H.: Management and Construction of the Three Gorges Project, J. Constr. Eng. M.-ASCE, 132, 615-619, 2006.

Dai, Z., Chu, A., Stive, M. J. F., and Yao, H.: Impact of the Three Gorges Dam Overruled by an Extreme Climate Hazard, Nat. Hazards. Rev., 13, 310-316, doi:10.1061/(ASCE)NH.15276996.0000081, 2012.

Diaz-Nieto, J. and Wilby, R. L.: A comparison of statistical downscaling and climate change factor methods: impacts on low flows in the River Thames, United Kingdom, Climatic Chang., 69, 245-268, doi:10.1007/s10584-005-1157-6, 2005.

Dong, G., Zhang, H., Moise, A., Hanson, L., Liang, P., and Ye, H.: CMIP5 model-simulated onset, duration and intensity of the Asian summer monsoon in current and future climate, Clim. Dynam., 46, 355-382, doi:10.1007/s00382-015-2588-z, 2016.

Ekström, M., Jones, P. D., Fowler, H. J., Lenderink, G., Buishand, T. A., and Conway, D.: Regional climate model data used within the SWURVE project - 1: projected changes in seasonal patterns and estimation of PET, Hydrol. Earth Syst. Sci., 11, 1069-1083, doi:10.5194/hess-11-1069-2007, 2007.

Ewen, J., Parkin, G., and O'Connell, P. E.: SHETRAN: distributed river basin flow and transport modeling system, J. Hydrol. Eng., 5, 250-258, doi:10.1061/(ASCE)10840699(2000)5:3(250), 2000.

FAO/IIASA/ISRIC/ISSCAS/JRC: Harmonized World Soil Database (version 1.2), FAO, Rome, Italy and IIASA, Laxenburg, Austria, 2012.

Fowler, H. J., Blenkinsop, S., and Tebaldi, C.: Linking climate change modelling to impacts studies: recent advances in downscaling techniques for hydrological modelling, Int. J. Climatol., 27, 1547-1578, doi:10.1002/joc.1556, 2007.

Ge, S., Wu, Q. B., Lu, N., Jiang, G. L., and Ball, L.: Groundwater in the Tibet Plateau, western China, Geophys. Res. Lett., 35, L18403, doi:10.1029/2008GL034809, 2008.

Hansen, M. C., Potapov, P. V., Moore, R., Hancher, M., Turubanova, S. A., Tyukavina, A., Thau, D., Stehman, S. V., Goetz, S. J., Loveland, T. R, and Kommareddy, A.: High-resolution global maps of 21st-century forest cover change, Science, 342, 850853, doi:10.1126/science.1244693, 2013.

Hayashi, S., Murakami, S., Xu, K. Q., Watanabe, M., and Xu, B. H.: Daily runoff simulation by an integrated catchment model in the middle and lower regions of the Changjiang basin, China, J. Hydrol. Eng., 13, 846-862, doi:10.1061/(ASCE)10840699(2008)13:9(846), 2008. 
Hock, R.: Temperature index melt modelling in mountain areas, J. Hydrol., 282, 104-115, 2003.

Immerzeel, W. W., Van Beek, L. P., and Bierkens, M. F.: Climate change will affect the Asian water towers. Science, 328, 13821385, doi:10.1126/science.118318, 2010.

Jiang, D. and Tian, Z.: East Asian monsoon change for the 21st century: Results of CMIP3 and CMIP5 models, Chinese Sci. Bull., 58, 1427-1435, doi:10.1007/s11434-012-5533-0, 2013.

Kingston, D. G., Todd, M. C., Taylor, R. G., Thompson, J. R., and Arnell, N. W.: Uncertainty in the estimation of potential evapotranspiration under climate change, Geophys. Res. Lett., 36, L20403, doi:10.1029/2009GL040267, 2009.

Knutti, R., Furrer, R., Tebaldi, C., Cermak, J., and Meehl, G. A.: Challenges in combining projections from multiple climate models, J. Climate, 23, 2739-2758, doi:10.1175/2009JCLI3361.1, 2010.

Koirala, S., Hirabayashi, Y., Mahendran, R., and Kanae, S.: Global assessment of agreement among streamflow projections using CMIP5 model outputs, Environ. Res. Lett., 9, 064017, doi:10.1088/1748-9326/9/6/064017, 2014.

Lee, J. Y. and Wang, B.: Future change of global monsoon in the CMIP5, Clim. Dynam., 42, 101-119, doi:10.1007/s00382-0121564-0, 2014.

Li, K., Zhu, C., Wu, L., and Huang, L.: Problems caused by the Three Gorges Dam construction in the Yangtze River basin: a review, Environ. Rev., 21, 127-135, doi:10.1139/er-2012-0051, 2013.

Li, X., Masuda, H., Koba, K., and Zeng, H.: Nitrogen isotope study on nitrate-contaminated groundwater in the Sichuan Basin, China, Water Air Soil Poll., 178, 145-156, doi:10.1007/s11270006-9186-y, 2007.

Liu, J., Zhang, Z., Xu, X., Kuang, W., Zhou, W., Zhang, S., Li, R., Yan, C., Yu, D., Wu, S., and Jiang, N.: Spatial patterns and driving forces of land use change in China during the early $21 \mathrm{st}$ century, J. Geogr. Sci., 20, 483-494, doi:10.1007/s11442-0100483-4, 2010.

Ma, Q., Xie, Z. H., and Zhao, L. N.: Variations of terrestrial water storage in the Yangtze River Basin under climate change scenarios, Atmos. Oceanic Sci. Lett., 3, 293-298, 2010.

McMahon, T. A., Peel, M. C., and Karoly, D. J.: Assessment of precipitation and temperature data from CMIP3 global climate models for hydrologic simulation, Hydrol. Earth Syst. Sci., 19, 361-377, doi:10.5194/hess-19-361-2015, 2015.

McSweeney, C. F., Jones, R. G., Lee, R. W., and Rowell, D. P.: Selecting CMIP5 GCMs for downscaling over multiple regions, Clim. Dynam., 44, 3237-3260, doi:10.1007/s00382-014-2418-8, 2015.

Milly, P. C. D. and Dunne, K. A.: Potential evapotranspiration and continental drying, Nature Climate Change, 6, 946-949, doi:10.1038/nclimate3046, 2016.

Moriasi, D. N., Arnold, J. G., Van Liew, M. W., Bingner, R. L., Harmel, R. D., and Veith, T. L.: Model evaluation guidelines for systematic quantification of accuracy in watershed simulations, T. ASABE, 50, 885-900, 2007.

Moss, R. H., Edmonds, J. A., Hibbard, K. A., Manning, M. R., Rose, S. K., Van Vuuren, D. P., Carter, T. R., Emori, S., Kainuma, M., and Kram, T.: The next generation of scenarios for climate change research and assessment, Nature, 463, 747-756, doi:10.1038/nature08823, 2010.
Nakićenović, N. J., Alcamo, G., Davis, B., De Vries, J., Fenhann, S., Gaffin, K., Gregory, A., Grubler, T., Jung, T., Kram, T., Lebre La Rovere, E., Michaelis, L., Mori, S., Morita, T., Pepper, W., Pitcher, H., Price, L., Riahi, K., Roehrl, A., Rogner, H.-H., Sankovski, A., Schlesinger, M., Shukla, P., Smith, S., Swart, R., van Rooijen, S., Victor, N., and Dadi, Z.: IPCC Special Report on Emissions Scenarios (SRES), Cambridge University Press, Cambridge, 2000.

Piao, S., Ciais, P., Huang, Y., Shen, Z., Peng, S., Li, J., Zhou, L., Liu, H., Ma, Y., Ding, Y., and Friedlingstein, P.: The impacts of climate change on water resources and agriculture in China, Nature, 467, 43-51, doi:10.1038/nature09364, 2010.

Prudhomme, C. and Williamson, J.: Derivation of RCM-driven potential evapotranspiration for hydrological climate change impact analysis in Great Britain: a comparison of methods and associated uncertainty in future projections, Hydrol. Earth Syst. Sci., 17, 1365-1377, doi:10.5194/hess-17-1365-2013, 2013.

Ragettli, S., Pellicciotti, F., Bordoy, R., and Immerzeel, W. W.: Sources of uncertainty in modeling the glaciohydrological response of a Karakoram watershed to climate change, Water Resour. Res., 49, 6048-6066, doi:10.1002/wrcr.20450, 2013.

Sanderson, B. M., O’Neill, B. C., Kieh, J. T., Meehl, G. A., Knutti, R., and Washington, W. M.: The response of the climate system to very high greenhouse gas emission scenarios, Environ. Res. Lett., 6, 034005. doi:10.1088/1748-9326/6/3/034005, 2011.

Schneider, U., Becker, A., Finger, P., Meyer-Christoffer, A., Ziese, M., and Rudolf, B.: GPCC's new land surface precipitation climatology based on quality-controlled in situ data and its role in quantifying the global water cycle, Theor. Appl. Climatol., 115, 15-40, doi:10.1007/s00704-013-0860-x, 2014.

Song, F. and Zhou, T.: Interannual variability of East Asian summer monsoon simulated by CMIP3 and CMIP5 AGCMs: Skill dependence on Indian Ocean-western Pacific anticyclone teleconnection, J. Climate, 27, 1679-1697, doi:10.1002/2013GL058705, 2014.

Sperber, K. R., Annamalai, H., Kang, I. S., Kitoh, A., Moise, A., Turner, A., Wang, B., and Zhou, T.: The Asian summer monsoon: an intercomparison of CMIP5 vs. CMIP3 simulations of the late 20th century, Clim. Dynam., 41, 2711-2744, doi:10.1007/s00382-012-1607-6, 2013.

Sperna Weiland, F. C., Tisseuil, C., Dürr, H. H., Vrac, M., and van Beek, L. P. H.: Selecting the optimal method to calculate daily global reference potential evaporation from CFSR reanalysis data for application in a hydrological model study, Hydrol. Earth Syst. Sci., 16, 983-1000, doi:10.5194/hess-16-983-2012, 2012.

Sunyer, M. A., Madsen, H., and Ang, P. H.: A comparison of different regional climate models and statistical downscaling methods for extreme rainfall estimation under climate change, Atmos. Res., 103, 119-128, doi:10.1016/j.atmosres.2011.06.011, 2010.

Tao, H., Gemmer, M., Jiang, J., Lai, X., and Zhang, Z.: Assessment of CMIP3 climate models and projected changes of precipitation and temperature in the Yangtze River Basin, China, Climatic Change, 111, 737-751, doi:10.1007/s10584-011-0144-3, 2012.

Taylor, K. E., Stouffer, R. J., and Meehl, G. A.: An overview of CMIP5 and the experiment design, B. Am. Meteorol. Soc., 93, 485-498, doi:10.1175/BAMS-D-11-00094.1, 2012.

Tian, D., Guo, Y., and Dong, W.: Future changes and uncertainties in temperature and precipitation over China based on CMIP5 
models, Adv. Atmos. Sci., 32, 487-496, doi:10.1007/s00376014-4102-7, 2015.

Wang, H. J., Sun, J. Q., Chen, H. P., Zhu, Y. L., Zhang, Y., Jiang, D. B., Lang, X. M., Fan, K., Yu, E. T., and Yang, S.: Extreme climate in China: Facts, simulation and projection, Meteorol. Z., 21, 279-304, doi:10.1127/0941-2948/2012/033, 2012.

Wang, J., Sheng, Y., Gleason, C. J., and Wada, Y.: Downstream Yangtze River levels impacted by Three Gorges Dam, Environ. Res. Lett., 8, 044012, doi:10.1088/1748-9326/8/4/044012, 2013.

Wang, Y., Ding, Y., Ye, B., Liu, F., and Wang, J.: Contributions of climate and human activities to changes in runoff of the Yellow and Yangtze rivers from 1950 to 2008, Sci. China Earth Sci., 56, 1398-1412, doi:10.1007/s11430-012-4505-1, 2012.

Woo, M. K., Long, T. Y., and Thorne, R.: Simulating monthly streamflow for the Upper Changjiang, China, under climatic change scenarios, Hydrolog. Sci. J., 54, 596-605, doi:10.1623/hysj.54.3.596, 2009.

Wösten, J. H. M., Lilly, A., Nemes, A., and Le Bas, C.: Development and use of a database of hydraulic properties of European soils, Geoderma, 90, 169-185, doi:10.1016/S00167061(98)00132-3, 1999

Xu, J., Yang, D., Yi, Y., Lei, Z., Chen, J., and Yang, W.: Spatial and temporal variation of runoff in the Yangtze River basin during the past 40 years, Quatern. Int., 186, 32-42, doi:10.1016/j.quaint.2007.10.014, 2008.
Yan, K., Ye, B., Zhou, D., Wu, B., Foken, T., Qin, J., and Zhou, Z.: Response of hydrological cycle to recent climate changes in the Tibetan Plateau, Climatic Change, 109, 517-534, doi:10.1007/s10584-011-0099-4, 2011.

Yang, S. L., Zhang, J., Zhu, J., Smith, J. P., Dai, S. B., Gao, A., and Li, P.: Impact of dams on Yangtze River sediment supply to the sea and delta intertidal wetland response, J. Geophys. Res., 110, F03006. doi:10.1029/2004JF000271, 2005.

Yang, Z. S., Wang, H. J., Saito, Y., Milliman, J. D., Xu, K., Qiao, S., and Shi, G.: Dam impacts on the Changjiang (Yangtze) River sediment discharge to the sea: The past 55 years and after the Three Gorges Dam, Water Resour. Res., 42, W04407, doi:10.1029/2005WR003970, 2006.

Yin, H. and Li, C.: Human impact on floods and flood disasters in the Yangtze River, Geomorphology, 41, 105-109, 2001.

Zhang, Q., Singh, V. P., Sun, P., Chen, X., Zhang, Z., and Li, J.: Precipitation and streamflow changes in China: changing patterns, causes and implications, J. Hydrol., 410, 204-216, doi:10.1016/j.jhydrol.2011.09.017, 2011.

Zhang, Z., Chen, X., Xu, C. Y., Yuan, L., Yong, B., and Yan, S.: Evaluating the non-stationary relationship between precipitation and streamflow in nine major basins of China during the past 50 years, J. Hydrol., 409, 81-93, doi:10.1016/j.jhydrol.2011.07.041, 2011.

Zhou, X. and Li, C.: Hydrogeochemistry of deep formation brines in the central Sichuan Basin, China, J. Hydrol., 138, 1-15, 1992. 